\title{
Ophiuroids Discovered in the Middle Triassic Hypersaline Environment
}

\author{
Mariusz A. Salamon ${ }^{1 *}$, Robert Niedźwiedzki ${ }^{2}$, Rafał Lach ${ }^{1}$, Tomasz Brachaniec ${ }^{3}$, Przemysław Gorzelak ${ }^{4}$ \\ 1 Department of Palaeontology and Biostratigraphy, University of Silesia, Faculty of Earth Sciences, Sosnowiec, Poland, 2 Institute of Geological Sciences, Wroclaw \\ University, Wroclaw, Poland, 3 Department of Geochemistry, Mineralogy, and Petrography, University of Silesia, Sosnowiec, Poland, 4 Department of Biogeology, Institute \\ of Paleobiology, Polish Academy of Sciences, Warsaw, Poland
}

\begin{abstract}
Echinoderms have long been considered to be one of the animal phyla that is strictly marine. However, there is growing evidence that some recent species may live in either brackish or hypersaline environments. Surprisingly, discoveries of fossil echinoderms in non-(open)marine paleoenvironments are lacking. In Wojkowice Quarry (Southern Poland), sediments of lowermost part of the Middle Triassic are exposed. In limestone layer with cellular structures and pseudomorphs after gypsum, two dense accumulations of articulated ophiuroids (Aspiduriella similis (Eck)) were documented. The sediments with ophiuroids were formed in environment of increased salinity waters as suggested by paleontological, sedimentological, petrographical and geochemical data. Discovery of Triassic hypersaline ophiuroids invalidates the paleontological assumption that fossil echinoderms are indicators of fully marine conditions. Thus caution needs to be taken when using fossil echinoderms in paleoenvironmental reconstructions.
\end{abstract}

Citation: Salamon MA, Niedźwiedzki R, Lach R, Brachaniec T, Gorzelak P (2012) Ophiuroids Discovered in the Middle Triassic Hypersaline Environment. PLoS ONE 7(11): e49798. doi:10.1371/journal.pone.0049798

Editor: Christopher Fulton, The Australian National University, Australia

Received July 9, 2012; Accepted October 12, 2012; Published November 19, 2012

Copyright: (c) 2012 Salamon et al. This is an open-access article distributed under the terms of the Creative Commons Attribution License, which permits unrestricted use, distribution, and reproduction in any medium, provided the original author and source are credited.

Funding: National Science Centre grant no. UMO-2011/01/B/ST10/02639, Institute of Geological Sciences of Wroclaw University grant no. 1017/S/ING/11-IV, the UPGOW project for financial support (Z481,2011/2012). This work was partially performed in the NanoFun laboratory co-financed by the European Regional Development Fund within the Innovation Economy Operational Programme POIG.02.02.00-00-025/09. The funders had no role in study design, data collection and analysis, decision to publish, or preparation of the manuscript.

Competing Interests: The authors have declared that no competing interests exist.

* E-mail: paleo.crinoids@poczta.fm

\section{Introduction}

Numerous studies dealing with salinity level and its impact on modern echinoderms showed that this parameter is important in terms of their spatial distribution and size [1-8]. In general, modern echinoderms have a more limited salinity range than any other invertebrates because they have a permeable body wall and lack differentiated osmoregulatory or excretory organs [2-9]. This limit can especially be drawn for fossil echinoderms, among which only stenohaline taxa have been documented. Although, some authors recently described Messinian echinoids from non-normal saline deposits deposited during evaporitic episode of the Mediterranean region [10], [11]; however, it seems that these echinoids [Brissopsis gr. lyrifera (Forbes)] occurred in interbedded horizons with rather normal(?) salinity (personal communication, A. Kroh, Naturhistorisches Museum Wien).

Intriguingly, in situ and labolatory experiments demonstrated that some extant echinoderms, in particular ophiuroids, asteroids and holothurians, can tolerate a great range of salinities [12]. So far, an ophiuroid Ophiophragmus filograneus (Lyman) constitutes an echinoderm species living in the lowest salinity in the field [13]. This form was found in the brackish facies of salinity level of $7.7 \%$. Remarkable salinity tolerance of this species has been also confirmed under laboratory conditions [14], [15]. Likewise, many authors draw attention to the fact that certain species of echinoderms can tolerate very low salinity [7-16]. Additionally, it has been pointed out that low salinity may lead to size abnormalities (dwarfism) [17-20].
On the other hand, echinoderms can tolerate hypersaline conditions (i.e., >35.5 psu according to [21]). For example, Price [22] reported two ophiuroid [Amphipholis squamata (Chiaje) and Amphiura fasciata Mortensen), and one holothurian (Leptosynapta chela Mortensen) species in Arabia Gulf with salinity ranging form 52 to $55 \%$. Furthermore, the latter author documented two stunted asteroid species (Astropecten polyacanthus phragmorus Fisher and Asterina burtowi Gray) in lagoons with salinity exceeding $60 \%$ which to date constitute the highest record for salinity tolerance by echinoderms in the wild.

In this paper, we report for the first time well-preserved ophiuroids Aspiduriella similis (Eck) from the Middle Triassic sediments of Poland that were deposited in hypersaline conditions.

\section{Materials and Methods}

\section{Geological Setting}

Abandoned quarry "Wojkowice" is situated in the so-called Silesian-Cracow Monocline, in Upper Silesia, Southern Poland (Figure 1). This monocline contains mainly Triassic sediments deposited in the Germanic Basin on the northern margin of the Tethys Ocean [23].

In Wojkowice, carbonate deposits of the Upper Buntsandstein (Röt or Roetian) as well as the lowermost part of the Lower Muschelkalk (the Lower Gogolin Beds and lowermost part of the Upper Gogolin Beds; lithostratigraphic division of the Lower Muschelkalk after [24]) are exposed (detailed description of the lithostratigraphy and paleontology of the Wojkowice Quarry see 


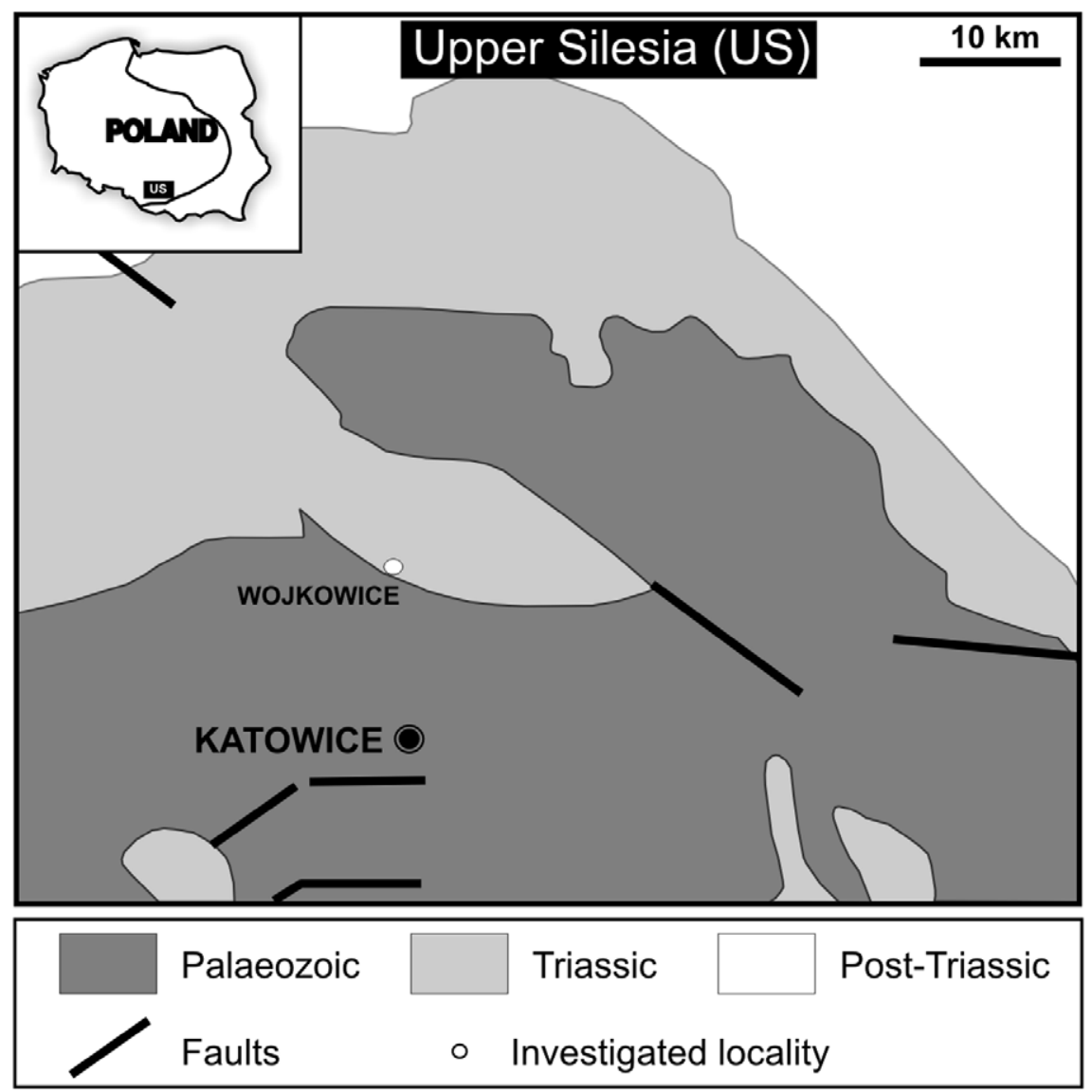

Figure 1. Fossil locality and geological setting. Map of Poland with investigated area indicated and enlargement of Upper Silesia with the sampled Wojkowice Quarry (circle). Figure slightly modified from [25]. doi:10.1371/journal.pone.0049798.g001

[25]; Figure 2A). Two ophiuroid accumulations were found in the Cellular Limestones Unit (the so-called "Zellenkalk 2") - uppermost lithological unit of the Lower Gogolin Beds. Its thickness in Wojkowice is up to ca. $1.3 \mathrm{~m}$. This unit represents Aegean [26]. The Cellular Limestones Unit is considered equivalent of the Grenzgelbkalk and Liegende Dolomite in Germany [23], [27] and crops out in the whole area in the Upper Silesia where the sediments of Lower Muschelkalk are present. The thickness of these sediments varies from 0.8 to $2.0 \mathrm{~m}$ depending on the locality [24]. In contrast to other units of the Gogolin Beds, body fossils are extremely rare in the Cellular Limestones Unit of Silesia. Only occasionally, bivalves: Hoernesia socialis (Schlotheim), Gervilleia mytiloides (Schlotheim), Myoconcha gastrochaena Dunker and isolated crinoid ossicles were recorded [24]. In numerous outcrops of this unit, body fossils are absent [28], [29]. Similarly, ichnofossils were not documented whereas they are numerous in the Lower Muschelkalk (e.g., [23]).

In Wojkowice, the Cellular Limestones Unit is represented by yellow dolomitic limestones and dolomitic marls. Lower part of this unit consists of dolomitic limestones. Above, a few $45 \mathrm{~cm}$ thick) layers are exposed [23]: palisade calcite layer, dolocrete layer, rauhwacke, cellular limestones and rauhwacke layer, respectively. In the upper part of the Cellular Limestones Unit, dolomitic limestones and marls are exposed. Two dense accumulations of ophiuroids have been found on the upper surface of the cellular limestone layer that was covered by a thin (ca. $2 \mathrm{~mm}$ ) muddy layer.

\section{Sampling}

During the field work about 28 square metres of the sediments of the Celullar Limestones Unit (including 4 square meters layer of cellular dolomitic limestone) were investigated (Figure 2). Fossils are extremely rare in this unit: we recorded only three poorly preserved bivalve molds and surprisingly two accumulations of ophiuroids (26 and 6 specimens) that were found within one horizon near the upper surface of the cellular dolomitic limestone layer (Figure 2C,D). Both accumulations were separated from each other by a distance of ca. $80 \mathrm{~cm}$. Additionally, three bulk samples from the cellular dolomitic limestone (each ca. $2 \mathrm{~kg}$ ) were taken and transported to the laboratory of the Department of Earth Sciences of University of Silesia. No specific permissions were required for collection of fossils form this location. Field studies were carried out at an abandoned quarry with public right-of-way and did not involve endangered or protected species.

Slabs with ophiuroids were initially cleaned with hot water. Later the samples were slightly treated using peroxide in order to clean them off from the remnants of the thin layer of muddy sediments and again washed with hot water. Slabs were dried and watched under a binocular microscope for taphonomic studies. All ophiuroids from the Celullar Limestones Unit were examined carefully for evidence of breakage, abrasion, dissolution, regeneration traces and evidence of bite marks. Three selected bulk samples of dolomitic limestone were dissolved using glauber salt $(8$ cycles of boiling-freezing procedure). Later they were washed using hot tap water and sieved using $\varnothing 0.5 \mathrm{~mm}, 0.315 \mathrm{~mm}$ and 
A
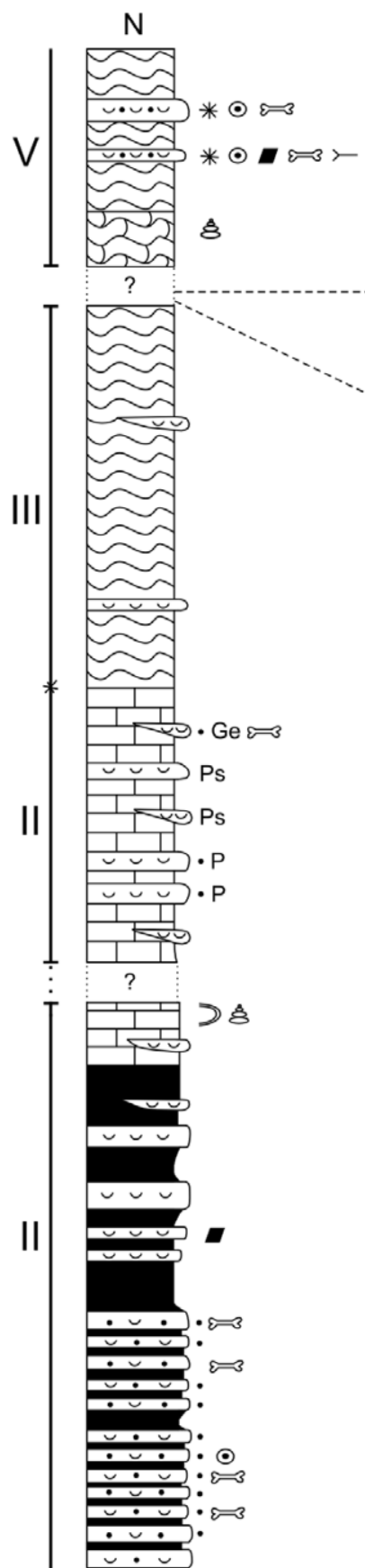

$\mathrm{S}$

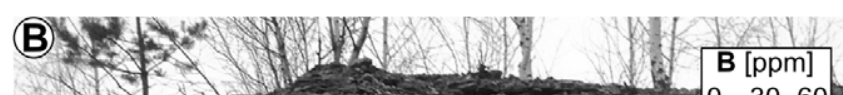
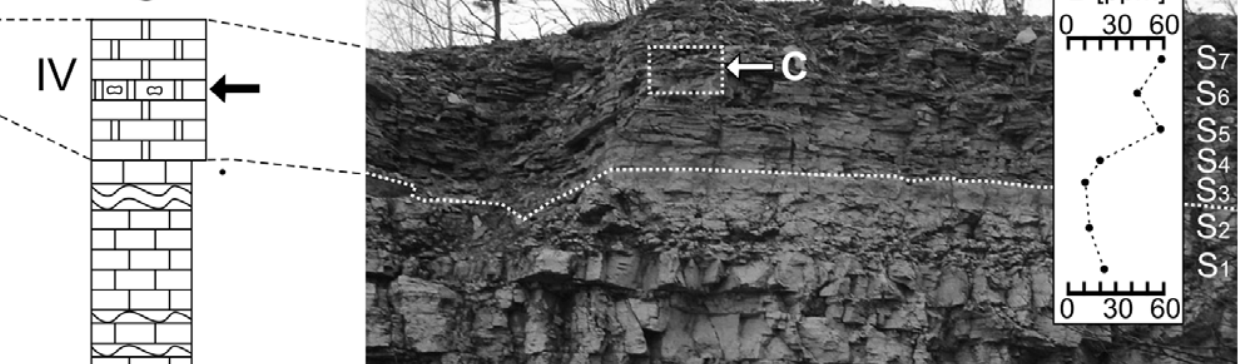

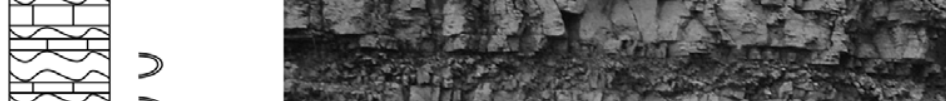

in

N1/

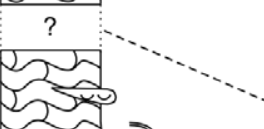

2त?

$\because \div \div \div \cdot \varepsilon=3$

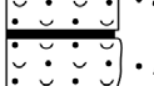

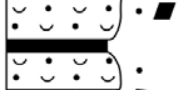

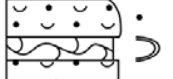

$\because \because$

$\because \because$

$\because \because ّ$

$\because \because u$

$\leftarrow 21$

* 20

$\succ \quad 19$

Ge 18

Ps 17

P 16

\& 15

$>14$

- 13

- 12

$\odot 11$

- 10

$\varepsilon=3 \quad 9$

20
201

펨 6

뜬 5

$\because:: 3$

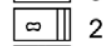

$\lceil 0,5 \mathrm{~m}$

$\| 1$
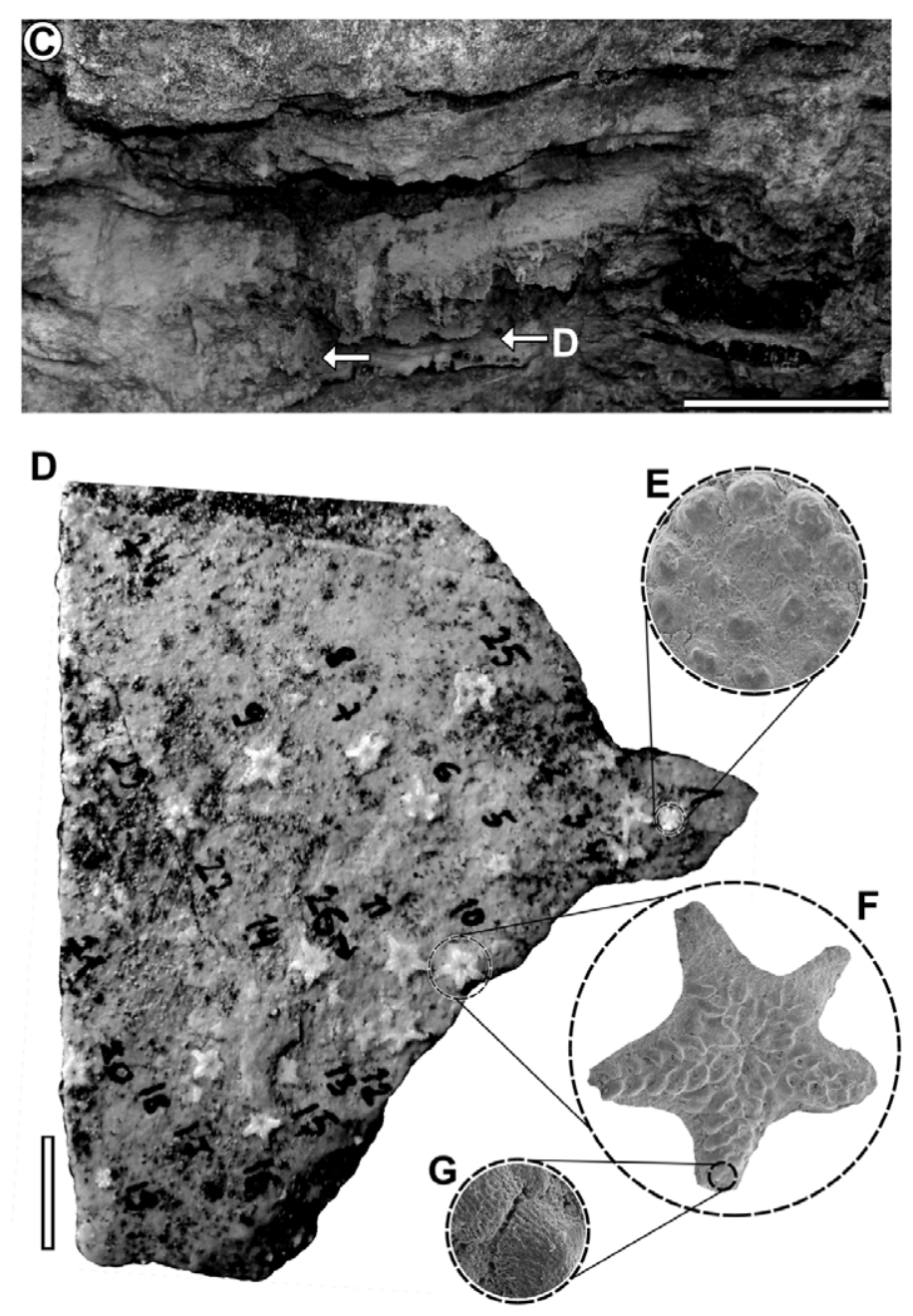
Figure 2. Stratigraphical section of Triassic sediments with ophiuroids. (A) Section of the northern and southern part of the Wojkowice Quarry (from [25]). 1, dolomitic limestones and marls; 2, cellular dolomitic limestones; 3, organodetrital limestones with bivalve detritus and columnals; 4 , marly limestones; 5 , pelitic limestones with abundance shells of bivalves; 6 , pelitic limestones; 7 , wavy limestones; 8 , nodular limestones; 9, vertebrate remains; 10 , Dadocrinus columnals; 11 , encrinid columnals; 12 , intraclasts; 13 , regurgitalites; 14 , Rhizocorallium commune; 15 , numerous gastropods; 16, numerous Plagiostoma; 17, numerous Pseudocorbula sp.; 18, numerous Gervillia sp.; 19, Thalassinoides; 20, Holocrinus columnals; 21, layer(s) with presently recorded ophiuroids. I, Roetian; II, "Iimestones with Entolium and Dadocrinus unit"; III, "first wavy limestones unit"; IV, "cellular limestones unit"; V, "thick-bedded limestones" and "wavy limestones unit". (B) Investigated section of "first wavy limestones unit" and "cellular limestones unit"; $S_{1}-S_{7}=$ rock samples for boron content analyses. Scale bar equals $1 \mathrm{~m}$. (C) Enlargement of the ophiuroid layer. Arrows show the place of accumulations. Scale $b a r=10 \mathrm{~cm}$. (D) Slab (described in the paper as no. 1) with ophiuroid accumulation. (E) SEM micrographs of the oral view of the ophiuroid disc. (F) SEM micrographs of the aboral view of the near complete ophiuroid specimen. (G) SEM micrographs of the contact of arm plates showing relicts of the stereom microstructure. Scale bar $=10 \mathrm{~mm}$. doi:10.1371/journal.pone.0049798.g002

$0.1 \mathrm{~mm}$ mesh widths. After drying in $180^{\circ} \mathrm{C}$, samples were screened under a binocular microscope.

\section{Petrographic and Geochemical Analyses}

Polished and carbon-coated thin sections of the samples from the Celullar Limestones Unit were examined with cathodoluminescence microscope equipped with a hot cathode integrated with spectograph and linked to a Kappa video camera for recording digital images, at the Institute of Paleobiology of the Polish Academy of Sciences in Warsaw. Integration times for CLemission spectra of luminescent samples were $50 \mathrm{~s}$. The cathodoluminescent properties of sections were additionally examined using the Cambridge Image Technology Ltd CCL 8200 mk3 model system with $12-15 \mathrm{kV}$ beam potential and $400 \mathrm{~mA}$ beam current attached to a NIKON ECLIPSE E400 Pol optical microscope at the Department of Stratigraphical Geology of Wrockaw University. The petrographical investigations were carried out at the Institute of Geological Sciences of Wrocław University and at the Institute of Paleobiology of the Polish Academy of Sciences in Warsaw.

Seven samples (two from limestones and five from dolomitic limestones) were selected for geochemical analysis (in particular boron content) using PGNAA (Pulsed Gamma Neutron Activation Analysis) method (Figure 2B). $1 \mathrm{~g}$ samples are encapsulated in a polyethylene vial and placed in a thermalized beam of neutrons produced from a nuclear reactor. Samples are measured for the doppler broadened prompt gamma ray at $478 \mathrm{KeV}$ using a high purity GE detector. Samples are compared to certified reference materials used to calibrate the system. A minimum of four standards are analyzed with every work order. Duplicates were analyzed to check method stability. The detection limit $(0.5 \mathrm{ppm})$ reported is a function of the counting times required for each.

The collections are housed at the Department of Palaeontology and Biostratigraphy of the University of Silesia, Sosnowiec, Poland (catalogue number GIUS 7-3601- Geological Institute of the University of Silesia).

\section{Results}

\section{Paleontology}

Macerated samples did not contain any macro- or microfauna. However, surprisingly two dense ophiuroid accumulations were found in the field on the surface of two slabs. These ophiuroids were scattered across the area of 15 and $30 \mathrm{~cm}^{2}$, respectively. The first accumulation yielded 26 specimens whereas the second yielded only 6 specimens. All specimens were represented by complete or nearly complete forms (disc plus arms or partly preserved arms; see details below). Only $6 \%$ of total number of ophiuroids (2 specimens) were preserved in situ, i.e., with oral side directing towards the bottom (more details in discussion).

Ophiuroid specimens lack clear evidences of abrasion, extensive dissolution, regeneration or bite mark traces (Figure 2E,F,G).
Three specimens yield (likely post-diagenetic) evidence of breakage (specimens no. 10 and 23 on the slab no. 1; specimens no. 2 on the slab no. 2; see Table 1,2). Most speciemens possess complete disc with partly preserved arms, i.e., $70 \%$ of speciemens lack distalmost part of arms. Two states of preservations can be distinguished:

1. Well-preserved ophiuroids (Taphonomic Group 1), with only minor signs of disarticulation (e.g., lack of distal arm portions);

2. More disarticulated specimens (Taphonomic Group 2) comprising central disc with attached less than five and partly preserved arms (having only proximal and median portions of their arms).

\section{Aspiduriella Description}

The ophiuroid assemblages from Wojkowice consist of monospecific and multiindividual accumulation with small ophiuroids Aspiduriella similis (Eck) with narrow range size $2.7-3.4 \mathrm{~mm}$ (Table 1,2). This species is thought to have been a slow-moving, low-level epifaunal detritivore and/or suspension feeder [30]. These ophiuroids have central disc of oval outline (Figure 2E). The center of the disc has a small and distinctly pentagonal centrodorsal plate. The first circlet of disc is composed of five hexagonal basal plates. The radial plates are relatively large and drop-shaped; they are covered by single and small protuberances on the radial position on each plate. Numerous and irregular secondary plates occur between basal and radial plates. The arms are rather short and their tips are usually not preserved. The lateral plates in the proximal part are narrow and low. The dorsal plates are smooth, romboid and decrease in size distally (Figure 2F). The ventral plates have sharp edges.

\section{Petrography and Geochemistry}

The cellular limestone layer consists of fine-grained, sometimes laminated and microfolded dedolomites with irregulary distributed voids built mainly of fine pseudospar crystals (Figure 3). Occasionally, pseudomorphs after gypsum (Figure 3E) and rhombohedral crystals of calcitized dolomite are observed. Some of them possess distinct zonal structures (Figure 3F). The dedolomites contain $\mathrm{Fe}-\mathrm{Mn}$ oxides and hydrooxides as suggested by cathodoluminescent analyses, i.e., non-luminescent zones are due to $\mathrm{Fe}^{2+}$ rich ("quencher ion") diagenetic fluids whereas bright orange luminescent areas are due to changing diagenetic fluid chemistry leading to $\mathrm{Mn}^{2+}$ incorporation ("activator ion"). The CL emission spectrum of an orange luminescing $\mathrm{Mn}^{2+}$-activated showed emission maximum at about $660 \mathrm{~nm}$ (Figure 4, $\mathrm{Mn}^{2+}$ activation in the $\mathrm{MgCO}_{3}$ position).

Geochemical analyses revealed that the boron is non-uniformly distributed within a part of investigated section. The main feature of boron distribution is a relatively low $\mathrm{B}$ concentration in the lower part of the section (10-23 ppm) and much higher 
Table 1. Taphonomic features of Aspiduriella similis from Celullar Limestones Unit (accumulation no 1).

\begin{tabular}{|c|c|c|c|c|}
\hline Specimen number & Disc diameter [in $\mathbf{m m}]$ & Life position: oral side up [u], down [d] & Breakage & Taphonomic group \\
\hline 1 & 2.7 & d & no & 1 \\
\hline 2 & 2.9 & $\mathrm{u}$ & no & 1 \\
\hline 3 & 3.0 & u & no & 2 \\
\hline 4 & 3.0 & u & no & 2 \\
\hline 5 & 3.1 & u & no & 2 \\
\hline 6 & 2.8 & u & no & 2 \\
\hline 7 & 3.2 & u & no & 2 \\
\hline 8 & 3.3 & u & no & 2 \\
\hline 9 & 3.2 & $\mathrm{u}$ & no & 2 \\
\hline 10 & 2.9 & u & yes & 2 \\
\hline 11 & 3.0 & $\mathrm{u}$ & no & 2 \\
\hline 12 & 2.9 & u & no & 2 \\
\hline 13 & 3.4 & $\mathrm{u}$ & no & 1 \\
\hline 14 & 3.1 & u & no & 2 \\
\hline 15 & 3.2 & u & no & 2 \\
\hline 16 & 2.8 & $\mathrm{u}$ & no & 2 \\
\hline 17 & 2.8 & u & no & 2 \\
\hline 18 & 2.9 & u & no & 2 \\
\hline 19 & 3.1 & $d$ & no & 1 \\
\hline 20 & 3.3 & $\mathrm{u}$ & no & 1 \\
\hline 21 & 3.2 & $\mathrm{u}$ & no & 1 \\
\hline 22 & 3.1 & $\mathrm{u}$ & no & 2 \\
\hline 23 & 3.0 & $\mathrm{u}$ & yes & 1 \\
\hline 24 & 2.8 & $\mathrm{u}$ & no & 1 \\
\hline 25 & 3.0 & $\mathrm{u}$ & no & 2 \\
\hline 26 & 3.1 & $\mathrm{u}$ & no & 1 \\
\hline
\end{tabular}

doi:10.1371/journal.pone.0049798.t001

concentration in upper part of the section (44-58 ppm) (see Figure 2B).

\section{Discussion}

\section{Depositional Paleoenvironment of Cellular Limestones Unit}

The Silesian Cellular Limestones Unit (Zellenkalk 2) was formed at the end of the highstand system tracts phase, when significant shallowing of the basin occurred [23]. This led to the temporarily emergence of the bottom and strong evaporation which is supported by isotopic data of $\delta^{13} \mathrm{C}$ and $\delta^{18} \mathrm{O}$ [23], [31]. The Cellular Limestones Unit has no evidence of marine intercalations and was presumably deposited in sabkha environment with a dominant sedimentation of lime mud [31]. Analogical cellular structures (cells) in cellular limestone in Silesian Roetian (Zellenkalk 1) are interpreted as voids after dissolved and removed gypsum and halite crystals [32]. Similar voids from Zellenkalk 2 of the same origin are observed (Figure $3 \mathrm{C}$ ).

Supra-normal salinity during deposition of this unit is supported by low abundance and diversity of fossils ( 3 bivalve molds and two opiuroid accumulations on 28 square metres investigated) and lack

Table 2. Taphonomic features of Aspiduriella similis from Celullar Limestones Unit (accumulation no 2).

\begin{tabular}{|c|c|c|c|c|}
\hline Specimen number & Disc diameter [in mm] & Life position: oral side up [u], down $[d]$ & Breakage & Taphonomic group \\
\hline 1 & 3.0 & $\mathrm{u}$ & no & 2 \\
\hline 2 & 2.8 & $\mathrm{u}$ & yes & 2 \\
\hline 3 & 2.7 & $\mathrm{u}$ & no & 1 \\
\hline 4 & 2.8 & $\mathrm{u}$ & no & 2 \\
\hline 5 & 2.9 & $\mathrm{u}$ & no & 2 \\
\hline 6 & 3.0 & $\mathrm{u}$ & no & 2 \\
\hline
\end{tabular}



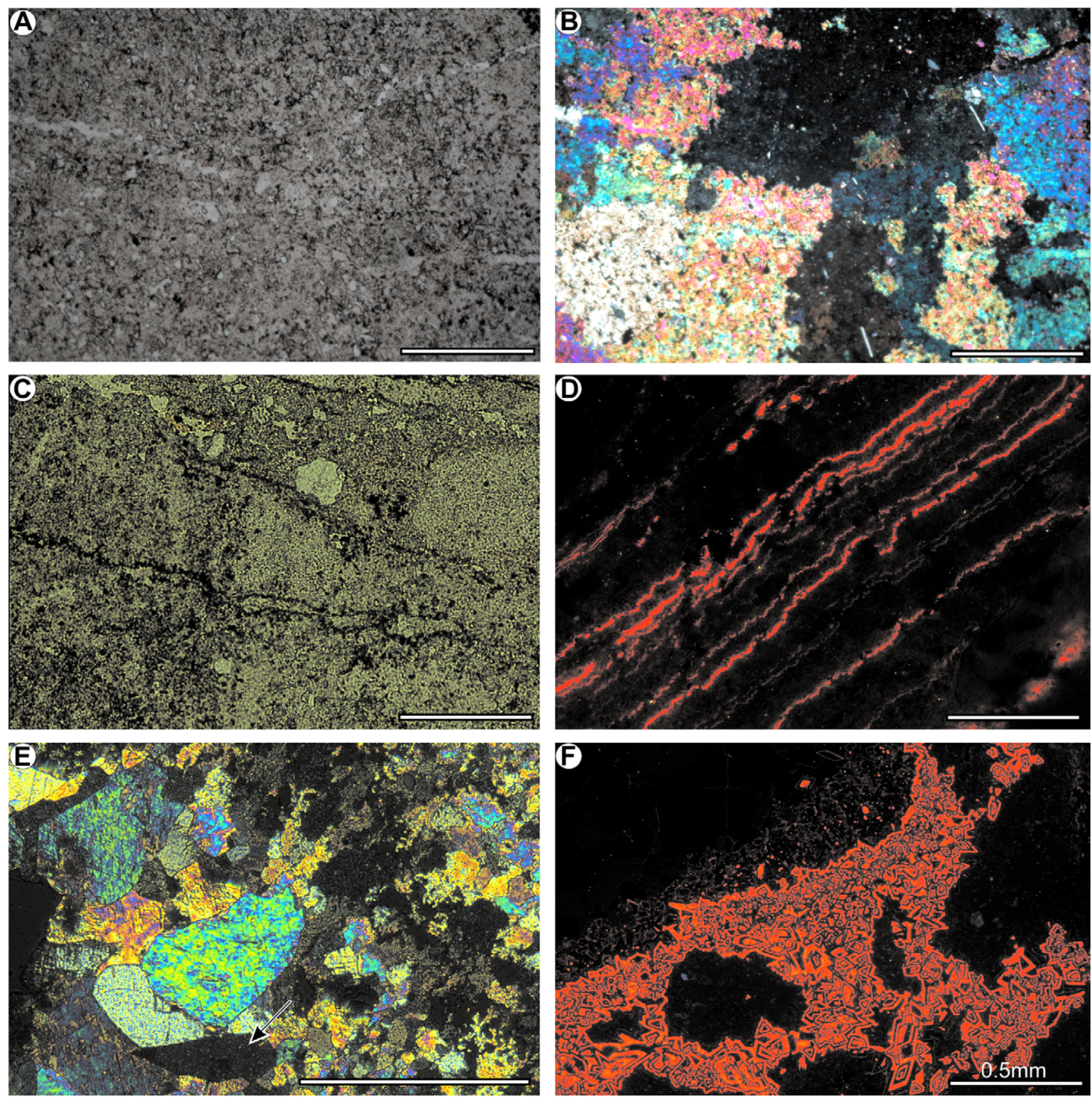

Figure 3. Petrographical and cathodoluminescent features of the layer with ophiuroids. (A) Fine-grained dedolomites under transmitted light and (B) in crossed-nicoles. (C) Laminated dedolomites with irregulary distributed voids under transmitted light. (D) Laminated and microfolded dedolomites under cathodoluminescence. (E) Pseudospar crystals and rhombohedral crystals of calcitized dolomites and pseudomorphs after gypsum (arrows) in crossed-nicoles. (F) Rhombohedral crystals of calcitized dolomites under cathodoluminescence showing zoned crystal growth. Dolomite rhomboids have non-luminescent and bright orange luminescent zones. Non-luminescent areas are due to Fe rich diagenetic fluids and the incorporation of $\mathrm{Fe}$ in the dolomite lattice ("quench ion") during crystal gwowth, bright orange luminescent areas indicates changes in the diagenetic fluid chemistry into $\mathrm{Mn}$ enrichment and the incorporation of $\mathrm{Mn}$ in the dolomite lattice ("activator ion") during crystal growth. doi:10.1371/journal.pone.0049798.g003

of ichnofossils. By contrast, fossils (especially crinoids) are numerous in the adjacent lithological units [25], [33]. It is noteworthy that previous studies have documented three bivalve species within the Cellular Limestones Unit: Hoernesia socialis (Schlotheim), Gervilleia mytiloides (Schlotheim), Myoconcha gastrochaena Dunker [24]. According to the literature [34], all these species are euryhaline. Especially, Hoernesia has been commonly reported in hypersaline deposits of Europe and Canada [34], [35].

The occurrence of some postevaporatic structures (including layer of palisade calcite and the rauhwacke layers) is also consistent with increased salinity interpretation [23] although according to some authors [31] the Cellular Limestones Unit comprises also early diagenetic evaporites. Additionally, our microfacial observa- 


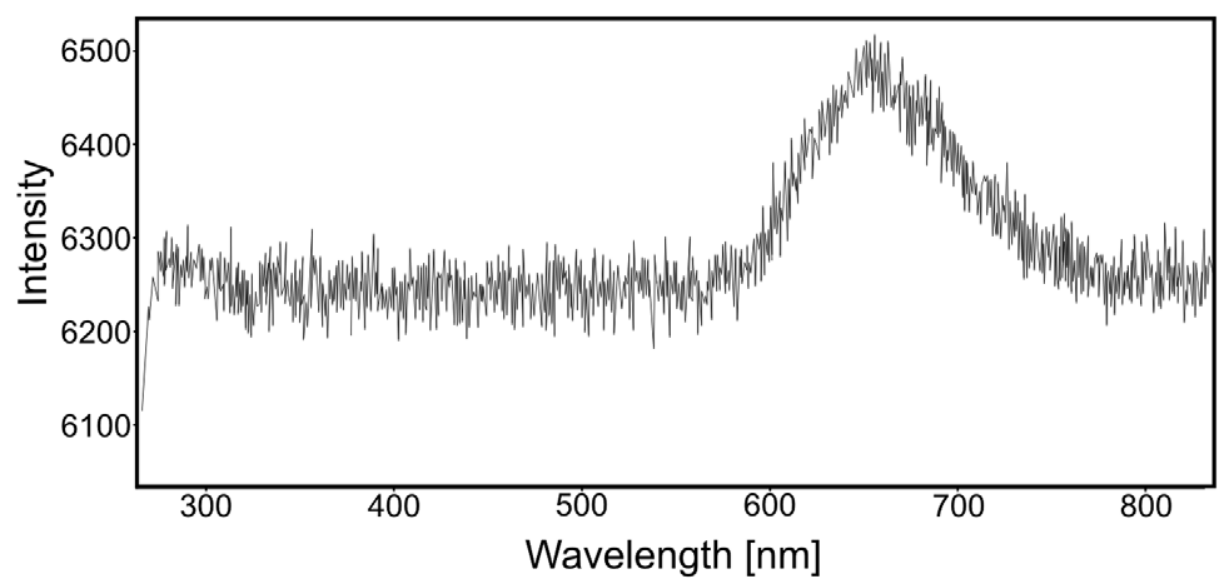

Figure 4. CL-activated UV-VIS spectrum of the luminescent dolomite (see Figure 3F). Spectrum shows $\mathrm{Mn}^{2+}$ emission maximum at ca. $660 \mathrm{~nm}\left(\mathrm{Mn}^{2+}\right.$ activation in the $\mathrm{MgCO}_{3}$ position). doi:10.1371/journal.pone.0049798.g004

tions indicate that within the Cellular Limestones Unit two standard microfacies types can be distinguished: SMF 23: Nonlaminated homogeneous micrite and microsparite without fossils (Figure 3A,C) and SMF 25: Laminated evaporite-carbonate mudstone (Figure 3D) which are both indicative of increased salinity (such as sabkha) environment [36]. It is worth mentioning here that an equivalent of the Silesian Cellular Limestones Unit in Thuringian Basin, the so-called Gelbkalke is also interpreted as saline dolomite formed in sabkha environment [37].

It has been argued that light stable isotopes $\left(\delta^{13} \mathrm{C}\right.$ and $\left.\delta^{18} \mathrm{O}\right)$ may be useful in paleosalinity reconstruction [38]. However, our petrographical data suggests that lime mud in Wojkowice underwent early diagenesis and later complete calcitization. Therefore, any isotopic analyses within this layer are herein impossible. Nevertheless, another important argument for an increased salinity comes from geochemical data. It has been suggested that boron content of the sediment shows a positive correlation with salinity and can be used as paleosalinity indicator [39-47]. However, many complexities (including diagenetic changes, different illite and organic carbon concentrations) can plague the use of boron as a paleosalinity proxy [48]. Nevertheless, other workers indicated a lack of correlation between boron concentration and either the clay-silt ratio or the percent organic carbon [47] as well as degree of diagenetic changes [49]. Results of our geochemical analyses indicate a remarkable boron concentration (up to about 58 ppm) in the Cellular Limestones Unit (Figure 2B). By contrast, boron concentration in the lower part of the section (considered fully marine) is more than twice lower.

\section{Origin and Taphonomy of Ophiuroid Accumulations from Wojkowice}

Considering the origin of ophiuroid accumulations described here, it is necessary to determine if these accumulations are autochthonous or allochthonous (e.g., transported from the nearshore part of the marine basin onto the sabkha by storms). Layer with ophiuroids, similarly to the adjoining layers, consists of fine-grained (mud fraction) sediment without any sedimentary structures which are indicative of high energy environment (e.g., intraclasts, channel erosion, ripple marks, grading). The top surface of the layer with ophiuroids is plain with no signs of erosion and is covered by an undeformed thin (ca. $2 \mathrm{~mm}$ ) muddy layer. The influence of incidental tidal sedimentation on the exposed and dried surface is also unlikely as such deposits typically yield characteristic structures (e.g. mudcracks, raindrops or herringbone cross-stratification) that are not seen within the investigated unit. Furthermore, transportation induces characteristic signs of abrasion on the ossicle surface which are not observed in studied ophiuroids (Figure 2E,F,G). Only 3 specimens yield evidence of (possibly post-diagenetic) breakage. If the sediment with ophiuroids was transported by storm, Cellular Limestones Unit should contain other macro- and microfossils (such as crinoids, foraminifers, ostracods) that are commonly present in marine deposits of the Gogolin Beds. However, in analysed samples macro- and microfossils were not documented (except bivalve molds). Admittedly, although lack of the distalmost parts of the arms in $70 \%$ of the specimens may be indicative of transport, it has been argued that storms do not appear to cause arm damage in extant living ophiuroids [50]. A possible explanation for that mode of preservation is that after the death, initially distalmost parts of the arms become disarticulated and as the smallest and the lightest ossicles they could have been easily transported. It cannot be completely excluded that some of the arms could have been also autotomized before death.

The found ophiuroids are generally classified within the first taphonomic group (Type 1 echinoderms; [51]). This group comprises echinoderms with ossicles that are held together only by soft tissues such as ligaments and muscles. These echinoderms do not remain articulated for very long after death because their ossicles are rapidly disarticulated by decay [51]. Therefore, the perfect state of preservation of our ophiuroids indicates rather short post-mortem seafloor exposure. Taken together, it seems that these ophiuroids appear to be para-autochthonous in that they have not been transported away from their life habitat.

Extant echinoderms living in hypersaline environments commonly display dwarfism [22], [52], [53]. Studied ophiuroids from Wojkowice are relatively small (max. disc diameter equals $3.4 \mathrm{~mm}$, mean disc diameter equals 3.0; see Table 1,2). However, data on size range as well as relationship between the size and the age of the specimens of Triassic Aspiduriella are rather sparse. Within the genus Aspiduriella several species have been documented: $A$. camuna (Rossi Ronchetti), A. dorae (Lepsius), A. italica (Crema), A. ludeni (von Hagenow), A. montserratensis (Calzada and Gutiérrez), A. scutellata (Blumenbach), A. similis (Eck) and A. streichani (Kutscher M.) [5458]. However, of these species only four are typical for the Muschelkalk Germanic Basin (A. ludeni, A. scutellata, A. similis and A. streichen $i$. The most reliable size data is the maximum disc 
diameter. A. ludeni occurring commonly in the Lower Muschelkalk of the Polish part of the Germanic Basin is the largest form with disks reaching up to $8.2 \mathrm{~mm}$. This form was also noted from the Lower Muschelkalk of the eastern Germany (Rüdersdorf near Berlin) [57], [59-61]. A. streichani is similarly-sized to A. ludeni and its disk reached up to ca. $8 \mathrm{~mm}$. This species is common only in the vicinity of the Lower Muschelkalk of Rüdersdorf [62]. However, it should be pointed out that the morphology of this species is very similar to the previously mentioned $A$. ludeni. Stoll [63] ascribed this taxon to $A$. ludeni with a question mark. $A$. scutellata with its maximum disk diameter equaling $6.9 \mathrm{~mm}$ occurs in the Lower and Upper Muschelkalk of Poland and Germany [54], [55], [62-64]. This species is the only one that also has been reported from the Tethyan Realm of Italy [65]. The maximum disk diameter of $A$. similis commonly occurring in the Lower Muschelkalk of Poland equals $5 \mathrm{~mm}$ [66]. Unfortunately, data on range size as well as mean size are sparse. Previous workers [30], [66] have mentioned that ophiuroids from various localities in Poland have mean disc diameter commonly not exceeding $3 \mathrm{~mm}$. However, these ophiuroid taphofacies are connected with transportation from their life habitat due to storm-related obrution events. In such cases, segregation of the skeletons is likely. Thus, data on mean disc diameter of these ophiuroid populations are probably underestimated. Therefore, given our current state of knowledge on ontogenesis of $A$. similis it is impossible to clearly state if ophiuroids from Wojkowice underwent dwarfism or not.

Good state of preservation (see taphonomic groups in Table 1,2) and an overall sedimentological context indicate that the death of ophiuroids was not caused by high-energy (storm or tidal) event. Predation is also not a likely cause of their death as ophiuroids do not display evidence of damages of their discs and arms (such as bite marks comparable to those observed in crinoids from the lower part of this section; [33], [67]). Furthermore, the Cellular Limestone Unit in the Wojkowice lacks potential body predatory fossils (e.g., cidaroids, crabs, hybodontid sharks) or ichnofossils (e.g., Thalassinoides, Rhizocorallium) that are ascribed to predatory decapods. Such fossils do not occur also in other outcrops of this unit in the Upper Silesia [23], [24], [68], [69].

One possible explanation is that the ophiuroids from Wojkowice died due to the gradual deterioration of environmntal conditions. In the unstable sabkha environment, progressive evaporation might have been stressful for ophiuroids. For example, subaerially weathered dolomites indicate that this area might have been episodically lifted up [23]. In such drying sabkha, elevated temperatures, increasing salinity, as well as progressive oxygen depletion might have been responsible for the ophiuroid death. The fact that nearly all ophiuroids are preserved with their oral side turned up is consistent with such interpretation as studies on modern ophiuroids from the Northern Adriatic Sea [70] indicate that oxygen depletion commonly leads to their arm-tipping and the accompanying uplifted disc [71-72]. This behaviour is

\section{References}

1. Smith GFM (1940) Factors limiting distribution and size in the starfish. J Fish Res Board Can 5: 84-103.

2. Binyon J (1961) Salinity tolerance and permeability to water of the starfish Asterias rubens. J Mar Biol Assoc U.K. 41: 161-174.

3. Binyon J (1962) Ionic regulation and mode of adjustment to reduced salinity of the starfish Asterias rubens. J Mar Biol Assoc U.K. 42: 49-64.

4. Binyon J (1972a) Physiology of Echinoderms. Oxford: Pergamon Press. $264 \mathrm{p}$

5. Binyon J (1972b) The effects of diluted seawater upon podial tissues of the starfish Asterias rubens. Comp Biochem Physiol 41: 1-6.

6. Shumway SE (1977) The effects of fluctuating salinities on four species of asteroid echinoderms. Comp Biochem Physiol 58: 177-179.

7. Pagett RM (1980) Tolerance to brackish water by ophiuroids with special reference to a Scotish sea loch, Loch Etive. In: Jangoux M, editor. Echinoderms: Present and Past. Rotterdam: A.A. Balkema. 223-229. generally interpreted as an attempt to reach higher oxygen concentrations. In such humped postures, ophiuroids are prone to overturn. Similar arm-tipping behaviour have been recorded elsewhere during hypoxia in modern opiuroid species, including Ophiura texturata (Linnaeus) [73], [74], O. albida (Forbes) [75], or Amphiura chiajei (Forbes) and A. filiformis (Müller) [76], [77]. Alternatively, other factors may have also contributed to such an inverted position. It is noteworthy that extant ophiuroids can change body posture to an upside down position, with oral side of the disc facing upward and arms raised above the disc [78]. Furthermore, these organisms can curl into a ball-shaped configuration leading to the overturn due to shift of the center of gravity. Finally, the inverted position of extant ophiroids has been also reported in ophiuroids escaping from sediments [79]. After the overturn of ophiuroids, initially distalmost parts of the arms became disarticulated (if not earlier autotomized) and as the smallest and the lightest ossicles could have been easily transported. Then, within several? days the speciemens must have been covered by thin ca. $2 \mathrm{~mm}$ thick layer of the sediment allowing their near-complete preservation [51].

\section{Conclusions}

Fossil echinoderms are generally considered ideal indicators of fully marine conditions. Thus they have been commonly used in paleoenvironmental reconstructions. For example, echinoderm fossils (in particular asterozoan traces) have recently warranted a re- interpretation of the depositional environment of Stuttgart Formation (Middle Keuper) from the non-open marine into fully marine environment [80]. Discovery of ophiuroid accumulations from the Middle Triassic of Poland constitutes the first and the oldest fossil record to our knowledge of echinoderms found in hypersaline environment. Our discovery suggests that some echinoderm species might have been euryhaline and imply that adaptation to increased salinity might have already appeared in the Middle Triassic. Therefore, great care needs to be exercised when using fossil echinoderm as paleoenvironmental proxies.

\section{Acknowledgments}

We would like to especially thank Dr. Monika Kowal-Linka (Adam Mickiewicz University) for useful comments and access to valuable bibliographic data, and Dr. Frederick Hotchkiss (The Marine and Paleobiological Research Institute, Massachusetts) for improving the English of this paper. Constructive comments by three anonymous reviewers greatly helped us to improve the manuscript.

\section{Author Contributions}

Conceived and designed the experiments: MAS RN PG. Performed the experiments: MAS RN RL TB PG. Analyzed the data: MAS RN RL TB PG. Wrote the paper: MAS RN PG.

8. Byrne RH, Kaltenbacher E, Waterbury R (1999) Autonomous in situ analysis of the upper ocean: construction of a compact, long pathlength absorbance spectrometer aimed at order-of-magnitude improvements in the sensitivity of spectrophotometric analysis. Sea Technol 40: 71-75.

9. Meglitsch PA (1972) Invertebrate Zoology, second edition. London: Oxford University Press. 834 p.

10. Lacour D, Néraudeau D (1999) Evolution of the biodiversity of Mediterranean irregular echinoids between the Late Miocene and the Present-Day. In: Camoin GF, Dullo WC, editors. Paleoceanology of reefs and carbonate platforms: Miocene to Modern. Publication de İAssociation des Sédimentologistes français 133-135.

11. Lacour D, Néraudeau D (2000) Évolution de la diversité des Brissopsis (Echinoidea, Spatangoida) en Méditerranée depuis la "crise messinienne": 
application paléoécologique aux B. lyrifera intragypses de Sorbas (SE Espagne): Geodiversitas 22: 509-523.

12. Boolootian RA (1966) Physiology of Echinodermata. New York: Interscience Publishers. 822 p.

13. Thomas LP (1961) Distribution and salinity tolerance in the amphiurid brittlestar Ophiophragmus filograneus (Lym, 1875). Bull Mar Sci 11: 158-160.

14. Turner RL, Meyer CE (1980) Salinity tolerance of the brackish-water echinoderm Ophiophragmus filograneus (Ophiuroidea). Mar Ecol Prog Ser 2: 249-256.

15. Talbot TD, Lawrence JM (2002) The effect of salinity on respiration, excretion, regeneration and production in Ophiophragmus filograneus (Echinodermata: Ophiuroidea). J Exp Mar Biol Ecol 275: 1-14.

16. Binyon J (1966) Salinity tolerance and ionic regulation. In: Boolootian RA, editor. Physiology of Echinodermata. New York: Wiley-Interscience. 359-377.

17. Stancyk SE, Shaffer PL (1977) The salinity tolerance of Ophiothrix anguata (Say) (Echinodermata: Ophiuroidea) in latitudinally separate populations. J Exp Mar Biol Ecol 29: 35-43.

18. MacGinitie GE (1939) Some effects on fresh water on the fauna of a marine harbor. Am Mid Nat 21: 681-686.

19. Brattström H (1941) Studien über die Echinodermen des Gebietes zwischen Skagerrak und Ostsse, besonders des Öresundes, mit einer Übersicht über die physiche Geographie. Undersökningar över Öresund 27: 1-329.

20. Gezelius G (1963) Adaptation of the sea urchin Psammechinus miliaris, to different salinities. Zool Bidr Uppsala 35: 329-337.

21. Andutta FP, Ridd PV, Wolanski EJ (2011) Dynamics of hypersaline coastal waters in the Great Barrier Reef. Est Coast Shelf Sci 94: 299-305.

22. Price ARG (1982) Western Arabian Gulf Echinoderms in high salinity waters and the occurrence of dwarfism. J Nat Hist 16: 519-527.

23. Szulc J (2000) Middle Triassic evolution of the northern Peri-Tethys area as influenced by early opening of the Tethys Ocean. Ann Societ Geol Polon 70: 148.

24. Assmann P (1944) Die Stratigraphie der oberschlesischen Trias. T. II, Der Muschelkalk. Abhandlungen des Reichsamts für Bodenforschung 208: 1-125.

25. Salamon MA, Niedźwiedzki R, Gorzelak P, Lach R, Surmik D (2012) Bromalites from the Middle Triassic of Poland and the rise of the Mesozoic Marine Revolution. Palaeogeogr Palaeoclimat Palaeoecol 321-322: 142-150.

26. Nawrocki J, Szulc J (2000) The Middle Triassic magnetostratigraphy from the Peri-Thetys basin in Poland. Earth and Planetary Science Letters 182: 77-92.

27. Hagdorn H (1991) The Muschelkalk in Germany - An Introduction. In: Hagdorn H, editor. Muschelkalk, A Field Guide. Wiedert, Korb: GoldschneckVerlag W.K. 7-21.

28. Popiel JS (1967) Litologia i stratygrafia dolnego wapienia muszlowego okolic Malni (Śląsk Opolski): Annales Universitatis Mariae Curie -Skłodowska. Sectio B. Geographia, Geologia, Mineralogia et Petrographia 22: 191-217.

29. Siedlecki S (1949) Zagadnienia stratygrafii morskich osadów triasu krakowskiego. Rocz Pol Tow Geol 18: 191-272.

30. Zatoń M, Salamon MA, Boczarowski A, Sitek S (2008) Taphonomy of dense ophiuroid accumulations from the Middle Triassic of Poland. Lethaia 41:47-58.

31. Kowal-Linka M (2010) Origin of cone-in-cone calcite veins during calcitization of dolomites and their subsequent diagenesis: A case study from the Gogolin Formation (Middle Triassic), SW Poland. Sedim Geol 224: 54 64

32. Bodzioch A, Kwiatkowski S (1992) Sedimentation and early diagenesis of the Cavernous Limestone (Roth) of Gogolin, Silesian - Kraków region, Poland. Ann Soc Geol Polon 62: 223-242.

33. Gorzelak P, Salamon MA, Baumiller TK (2012) Predator-induced macroevolutionary trends in Mesozoic crinoids. Proc Natl Acad Sci U S A 109: 7004 7007.

34. Senkowiczowa H (1962) Wpływy fauny alpejskiej w osadach retu i wapienia muszlowego na obszarach Polski. In: Ksiega Pamiatkowa ku czci prof. Jana Samsonowicza. Polska Akademia Nauk, Warszawa. 239-255.

35. Gibson DW, Poulton TP (1994) Field guide to the Triassic and Jurassic stratigraphy and depositional environments. In: The Rocky Mountain Foothills and Front Ranges in the Banff, Jasper and Cadomin Areas, Alberta. Geological Survey of Canada, Open File Report No.2780. 1-85.

36. Flügel E (2004) Microfacies of Carbonate Rocks. Analysis, Interpretation and Application. Berlin: Springer-Verlag. 976 p.

37. Assaruri M, Langbein R (1990) Dolomitische Gelbkalke des Unteren Muschelkalks (Mittlere Trias) im Thüringer Becken. Zeit Geolog Wissensch 18: 1011-1016.

38. Keith ML, Weber JN (1964) Carbon and oxygen isotopic composition of selected limestones and fossils. Geochim Cosmochim Acta 28: 1787-1816.

39. Landergren S (1945) Distribution of boron in some Swedish sediments, rocks and iron-ores. Arkiv För Kemi, Mineralogi och Geologi 19A: 1-31.

40. Landergren $\mathrm{S}$ (1958) On the distribution of boron on different size classes in marine clay sediments. Geologiska Föreningens Stockholm Förhandlinger 80: 104-107.

41. Degens ET, Williams EG, Keith ML (1957) Environmental studies of carboniferous sediments: Part I. Geochemical criteria for differentiating marine and fresh water shales. Am Assoc Petrol Geol Bull 41: 2427-2455.

42. Degens ET, Williams EG, Keith ML (1958) Environmental studies of carboniferous sediments: Part II. Application of geochemical criteria. Am Assoc Petrol Geol Bull 42: 981-997.

43. Ernst W (1963) Diagnoze der Salinitatfazies mit Hilfe des Bors. Fortschritte in der Geologie von Rheinland und Westfalen 10: 253-266.
44. Walker CT, Price NB (1963) Departure curves for computing paleosalinity from boron in illites and shales. Am Assoc Petrol Geol Bull 47: 833-841.

45. Ernst W, Krejcl-Graf K, Werner H (1958) Farallelisering von Leithorizonten im Ruhrkaroon mit hilf des Bor-Gehaltes. Geochim Cosmochim Acta 14: 211-222.

46. Potter PE, Shimp NF, Witters J (1963) Trace elements in marine and fresh-water argillaceous sediments. Geochim Cosmochim Acta 21: 669-694.

47. Boon JD, Macintyre WG (1968) The boron-salinity relationship in estuarine sediments of the Rappahannock river, Virginia. Chesapeake Science 9: 21-26.

48. Hirst DM (1962) The geochemistry of modern sediments from the Gulf of Paria II: The location and distribution of the trace-elements. Geochim Cosmochim Acta 26: 1147-1187.

49. Frederickson AF, Reynolds RCJr (1960) Geochemical method for determining paleosalinity. Proc 8th Natl Conf on Clays and Clay Minerals (Pergamon Press). 203-213.

50. Sköld M, Rosenberg R (1996) Arm regeneration frequency in eight species of ophiuroidea (Echinodermata) from European sea areas. J Sea Res 35: 353-362.

51. Brett CE, Moffat HA, Taylor WL (1997) Echinoderm taphonomy, taphofacies, and Lagerstatten. In: Waters JA, Maples CG, editors. Geobiology of echinoderms. The Paleontological Society Papers 3: 147-190.

52. Twitchett RJ (2006) The palaeoclimatology, palaeoecology and palaeoenvironmental analysis of mass extinction events. Palaeogeogr Palaeoclimatol Palaeoecol 232: 190-213.

53. Twitchett RJ, Feinberg JM, ÒConnor DD, Alvarez W, McCollum LB (2005) Early Triassic ophiuroids: their paleoecology, taphonomy, and distribution. Palaios 20: 213-223.

54. Kutscher F (1940) Ophiuren-Vorkommen im Muschelkalk Deutschlands. Zeit d Deut Geol Ges 92: 1-18.

55. Hess H (1965) Trias-Ophiuren aus Deutschland, England, Italien and Spanien. Mitteilungen der Bayerischen Staatssammlung für Paleontologie und Historische Geologie 5: 151-177.

56. Hess H (1970) Ein neuer Schlangenstern (Aplocoma mutata n.sp.) aus dem Hettangien von Ceilhes (Hérault) und Bemerkungen über "Ophioderma" squamosa aus dem Muschelkalk. Eclogae Geol Helv 63: 1059-1067.

57. Kutscher M (1987) Aspidura streichani sp.n. - eine neue Ophiuren-Art aus dem Muschelkalk von Rüdersdorf. Zeit Geol Wissensch 15: 703-707.

58. Bolette DP (1998) Taxonomic note: Aspiduriella nom.n. for the genus Aspidura Agassiz, 1835 (Echinodermata: Ophiuroidea: Ophiuridae); preoccupied by Aspidura Wagler, 1830 (Reptilia: Serpents: Colubridae). J Paleontol 72: 401-402.

59. von Hagenow F (1846) Aspidura Ludeni. Paläontographica 1: 21-22.

60. Schmidt M (1928) Die Lebewelt unserer Trias. F. Rau, Öhringen. 1-461.

61. Radwański A (2002) Triassic brittlestar beds of Poland: a case of Aspiduriella ludeni (v. Hagenov, 1846) and Arenorbis squamosus (E. Picard, 1858). Acta Geol Pol 52: 395- 410.

62. Hagdorn H, Simon T (1985) Geologie und Landschaft des Hohenloher Landem. Jan Thorbecke Verlag, Sigmaringen. 1-186.

63. Stoll A (1980) Neue Funde von Ophiuroidea aus dem Muschelkalk von Rüdersdorf bei Berlin. Z Geol Wissenschaft 8: 929-932.

64. Eck H (1865) Über die Formationen des bunten Sandsteins und des Muschelkalks in Oberschlesien und ihre Versteinerungen. Berlin. 149 p.

65. Calzada S, Gutiérrez D (1988) Ofiuras (Echinodermata) del Ladiniense catalán. Battaleria 1: 31-38.

66. Salamon MA (2004) High-density populations of the Triassic ophiuroid Aspiduriella similis (Eck) from the Holy Cross Mountains (Central Poland) a preliminary report. Paläontologie, Stratigraphie, Fazies, Freiberger Forschungshefte 12: 1-4.

67. Baumiller TK, Salamon MA, Gorzelak P, Mooi R, Messing ChG, et al. (2010) Post-Paleozoic crinoid radiation in response to benthic predation preceded the Mesozoic marine revolution. Procl Natl Acad Sci USA 107: 5893-5896.

68. Assmann P (1937) Revision der Fauna der Wirbellosen der oberschlesischen Trias. Abhandlungen der Preußischen Geologischen Landesanst alt, Neue Folge 170: $1-134$.

69. Hagdorn H, Głuchowski E (1993) Palaeobiogeography and Stratigraphy of Muschelkalk Echinoderms (Crinoidea, Echinoidea) in Upper Silesia. In: Hagdorn H, Seilacher A, editors. Muschelkalk. Schöntaler Symposium 1991. Stuttgart: Sonderbände der Gesellschaft für Naturkunde Württemberg, Goldschneck. 165-176.

70. Riedel B, Zuschin M, Haselmair A, Stachowitsch M (2008) Oxygen depletion under glass: Behavioural responses of benthic macrofauna to induced anoxia in the Northern Adriatic. J Exp Mar Biol Ecol 367: 17-27.

71. Diaz RJ, Rosenberg R (1995) Marine benthic hypoxia: a review of its ecological effects and the behavioural responses of benthic macrofauna. Oceanogr Mar Biol Annu Rev 33: 245-303.

72. Hagerman L (1998) Physiological flexibility; a necessity for life in anoxic and sulphidic habitats. Hydrobiol 375/376: 241-254.

73. Dethlefsen V, Westernhagen $\mathrm{H}$ (1983) Oxygen deficiency and effects on bottom fauna in the eastern German Bight. Meeresforschung 30: 42-53.

74. Dries RR, Theede H (1974) Sauerstoffmangelresistenz mariner Bodenevertebraten aus der Westlichen Ostsee. Mar Biol 25: 327-333.

75. Baden SP, Loo L, Pihl L, Rosenberg R (1990) Effects of eutrophication on benthic communities including fish. Swedish west coast: Ambio 19: 113-122.

76. Rosenberg R, Hellman B, Johansson B (1991) Hypoxic tolerance of marine benthic fauna. Mar Ecol Prog Ser 79 127-131. 
77. Vistisen B, Vismann B (1997) Tolerance to low oxygen and sulfide in Amphiura filiformis and Ophiura albida (Echinodermata: Ophiuroidea). Mar Biol 128: 241246.

78. Shroat-Lewis R A (2007) Taphonomy of a Pliocene ophiuroid mass mortality lagerstätte in the Tirabuzón Formation, Baja California sur. Master Thesis of the University of North Carolina at Wilmington. 70 p.
79. Ishida Y, Fujita T (2000) Escape behavior of epibenthic ophiuroids buried in the sediment: observations of extant and fossil Ophiura sarsii sarsii. In: Barker M, editor. Proceedings of the 10th International Echinoderm Conference. Dunedin.pp. 285-292.

80. Schlirf M (2012) Heliophycus seilacheri n. isp. and Biformites insolitus linck, 1949 (trace fossils) from the Late Triassic of the Germanic Basin: their taxonomy and palaeoecological relevance. N Jb Geol Paläont Abh 263: 185-198. 